\title{
WHEREWITH SHALL IT BE SALTED?
}

\section{(An Inaugural Address to the University College, Aberystwyth.)}

When I was a boy in Australia I once saw a man who was an M.A. I had heard of M.A.s before; but that was the first occasion on which I actually saw one, and I remember still the thrill of admiration that went through me. The man seemed to me to represent unknown heights and deeps of learning; I took for granted that he possessed enlightened views and a noble character, and I had a sudden feeling that most questions might be settled by just asking such a man and taking his advice. The idea of becoming an M.A. myself did not enter my head. But $I$ did conceive a desire to hang on somewhere about the skirts of learning, and live perhaps in the service of M.A.s.

As things have turned out, this spirit of veneration has gradually fallen away from me. Perhaps $I$ have seen too much of M.A.s.

Yet I believe that my original feeling is in the first place shared by very many people, and in the second, is on the whole a sound and good one.

Since this College was founded in the early seventies, to grow into its place in the University of Wales in 1903, there has been a most remarkable movement all over Great Britain showing an increase in the desire for higher knowledge among classes of people who formerly either despised it or had no hope of it. Scotland had always been strong and keen in the pursuit of learning; but in Scotland, too, there has been a great advance. Wales has started from a place far behind in the race and has come with immense impetus to the very forefront. And England, which had, when I was at school, only four universities, Oxford, Cambridge, Durham, and the comparatively new Examining Body in London, is now studded with them. The new universities are all flourishing institutions, full of zeal and full of achievement; and behind them there is a vast network of organizations working in different ways for the increase of knowledge. There is the 
University Extension movement, the new Workers' Educational Association, many dozens of polytechnics, Athenzums, institutes, reading unions, and the like.

Now, in the first place, the existence of all these bodies indicates, unless I am mistaken, that there is a love of knowledge in this kingdom far more vigorous and widespread than at any previous time in our history; and in the second place, these bodies have called into being a new social class, a class which is sure to grow in numbers and which, I devoutly hope, will grow still more in social and political influence. It is about this class and its possible influence on the next two or three generations that $I$ wish to speak to you to-night.

Of course we have always had learned men; we have had universities possessed of great erudition and most devoted teachers, universities which still take, and I think take easily, the lead in the subjects of study to which they specially devote themselves. But I am taking to-night one particular point of view, that of Social Service. And, from the point of view of Social Service, I feel that here we are confronted with one of the great surprises, one of the great disappointments, of history. All through this troubled movement of the nations which has led from many mediæval darknesses to the comparatively cheerful twilight of modern European democracy, how strangely small a part has been played by the universities and the most highly educated classes ! They led in the Reformation; they led in the Renaissance. But since then? If you take the history of those great reforms which serve as touchstones to discover the real conscience, the real living thought, of the various Western nations-abolitions of slavery, abolitions of torture, reforms of the criminal law, removals of the hindrances to knowledge, and the like-how strangely seldom have the specially educated classes, the professed intellectual institutions of the various nations, taken the lead which by rights belonged to them! It was they who should have been the salt of the earth. They should have been what they were in France during the Dreyfus case. The case against the Intellectuals is almost as strong as the case against the Churches, at least the richest and most highly influential Churches. They also should have been the salt of the earth.

Many people, I know, are driven by considerations of this kind into a general contempt for culture and learning. They point to the votes of University members in Parliament, and say that that is what the higher education comes to. But $I$ think this is unfair. 
It is rather a curious and significant fact that throughout nearly the whole of history the intellect of every country has been, directly or indirectly, in the service of the rich. It was not so perhaps in ancient Athens; it was not so in the time of the Commonwealth; in a sense it was not so in the great age of the French Encyclopedists, in Germany in the thirties and forties. And all such times have been extraordinarily fruitful. Obstructive Intellect can be a sinister thing, though perhaps not so bad as obstructive stupidity; but free Intellect is, humanly speaking, the great hope of the world.

The new universities-and all this applies still more strongly to the various organisations from working men's night classes upward which belong to the same movement-are entirely free from the ecclesiastical atmosphere in which Oxford and Cambridge were nurtured. Their fees and their whole scale of expenses are immensely lower. They are free from that peculiar institution of the old universities, the rich idle pass-man, to whom is due almost all that occasionally brings Oxford and Cambridge into discredit with the rest of the country. For these reasons and many more, the new universities, if not actually democratic-for I doubt if they will ever in the fullest sense be that-will at least not be universities for the rich or dependent mainly on the patronage of the rich. So far as they turn out year by year a body of learned or intellectual men and women, the force and value of those men and women will not be hampered at the outset by something which puts them in antagonism to the main forward movement of their country. There will be a new and much larger intellectual class which will, be, comparatively speaking, free.

I idealize nobody. This new class, like all others, will certainly have its limitations and its prejudices. It will have a middle-class bias. It will have a nonconformist bias, a Puritan bias. It may. have, though possibly here the Celtic elements will have a softening effect, a preponderance of the harder and rougher virtues-selfrespect, thrift, caution, and the like. It must of necessity lack, at least for a time and to some degree, the ease of life, the wide culture, the freedom of outlook, of the best product of the older universities. But, all deductions made, I believe immensely in the power for good of this new class of Intellectuals; and I want, after this long preface, to consider with you some of the problems and social difficulties which you and your spiritual children will be called upon to face and in which I believe that you more than others may help our country. 
First of all, then, I expect good for the country from you and your class in the matter of money and the love of money. I need not waste words to show the immense part that the love of money plays in all modern civilisations. It intensifies all elements of corruption. It intensifies all elements of cruelty. In any commercial community a very large number of people must habitually be occupied with the thought: "How can I give to others the least possible, how can I get from them in return the most possible?" And that is not a very elevating train of thought.

Of course there is nothing specially new about the so-called commercial spirit which critics find in our present civilisation. The literature of all ages known to me makes just the same complaints that we make to-day. I expect the cattle dealers cheated one another in the days of $\mathrm{Og}$, King of Bashan. But I think that in the course of history something of this sort happens. Men, by means of public opinion, custcm, moral effort and the like, become able to bear the amount of strain or temptation to which they are normally exposed. You have an honest society. And then, at particular moments, a harder strain, a more insidious temptation, is brought to bear upon them, and their resistance fails. You have a corrupt society. When enormous prizes are in the air common honesty becomes a difficult virtue. And I think you will generally find that, when societies become corrupt in money matters, it means that new and larger prizes have been dangled before them. Think of the last phase of the Roman Republic, or England at the beginning of the 18 th century. We constantly hear on this side of the water about the corruption of America; but I often wonder how large a proportion of decent mercantile Englishmen would successfully withstand the dazzling temptations that lie in the way of a big American financier. Now, at the present day, it looks as if in many walks of life the prizes were becoming greater; the size of men's fortunes is increasing, the actual power of the money itself seems to me to be greater. It can buy more things. That means that this dangerous and antisocial passion, the love of money, is probably going to increase upon us. I want you and your class to help in stemming that danger.

Let us of course be sensible. Every normal person likes to have money; we most of us like to have as much as ever we can get without some undue sacrifice. I do not for a moment claim that Intellectuals will be indifferent to money. But I do claim that persons of intellect and imagination, persons who have 
definite tastes and ideals and things that they love, are always conscious of a great many other values in life besides money. People with no intellect or imagination tend to be conscious of money values alone. The stupidest and vulgarest of men can see the difference between a poor man and a rich; can appreciate the charms of a fur coat and a motor and unlimited champagne. We become removed from vulgarity and stupidity almost exactly in proportion as we begin to know and feel other values besides these.

The old universities can serve us as a model here. The Oxford and Cambridge colleges are full of men of very high ability and industry; men who would probably have been near the head of any profession they had taken up, and earned their thousands a year. They prefer to teach and study, getting as many hundreds. And I doubt if there is any place in the world where men are so little measured by their incomes as at Oxford and Cambridge.

And I think that this freedom from the standard of mere money holds through almost all the intellectual classes, and very much in proportion to the reality of their intellectual interests. I have never in my life heard a man of letters, I have never heard a scholar, poet, artist, or man of science, speak disparagingly of another because he was poor or unsuccessful. I have very seldom so much as suspected them of thinking disparagingly.

If we can get in Great Britain a large and strong class of people with whom the getting of money is not the first nor the second nor the third among the motive forces of their lives, and who never dream of valuing their fellow-creatures according to their incomes or their various degrees of social display, I think it is hard to realize how much peace, how much hope for the future it would bring us.

Let me consider one aspect of this. If you read almost any of the great English novelists, but above all Thackeray, you will be struck by the great social force of what is called "snobbishness." I will leave the word unanalysed; we all know roughly what it means.

Snobbishness is said to be a peculiarly British institution; and I think we can make out its historical causes. They are, roughly speaking, two in number, and both rather creditable than otherwise. On the one hand the English aristocracy has succeeded in the main in keeping up its prestige. The instinctive veneration with which the 18 th century regarded its noblemen has not been shattered in England by any great storm of hatred. And on the other hand, owing to a number of conditions which any student of 
history can think out, there is in England no vast and sudden cleavage between one class and another; in particular no gulf between the bourgeois and the noble. It is quite easy in England for almost every class to imitate or assume the manners and habits of the class just above it. And being easy, this process has been found highly attractive.

Imitation is not a bad thing. Most moral advance springs from imitation of some kind or else from the negative of imitation, conscious avoidance. And the enthusiastic imitation of the ruling class which has permeated England for at least a century has had its very good side. Of course it has its bad side; no one doubts that. It cozes away into all the innumerable forms of snobbishness, of which the key-note is false pretence, and which aims at the imitation of externals or even of vices, if only they seem like marks of wealth or rank. But $I$ think there is something fine in a nation in which practically every decent male, however poor, feels touched in the point of honour if it is suggested that he has " not behaved like a gentleman." The imitation of the ruling class has led to an extraordinarily wide insistence on what one may call the aristocratic virtues, on the sense of honour, on chivalry, on truthfulness -at least within certain limits, on an avoidance of obvious meannese-at least in public.

All this sort of thing may be very vulgar and may be rather noble. And $I$ believe that if we can get in this country a large and self-respecting mass of intellectual men and women, we shall make this ideal of gentlemanliness far more intelligent and sincere. The outside elements of pretence, class pride, snobbishness, will tend to dwindle; but we shall have more than before of the inward elements of courtesy, the sense of honour, confidence, kindliness and personal dignity.

I should like to dwell longer on the difference that this spread of courtesy will make in all the business of life, in human effectiveness as well as human happiness. But I will content myself with one remark. If these qualities-courtesy, friendliness and the like - seem to you to be among the lighter and more trivial virtues, remember that they are naturally, and almost of necessity, mutual. And therefore they must be based upon the previous existence of a number of very solid virtues indeed. No society can hope to be really courteous, in which there are many dishonest people, many bitter, spiteful or treacherous people. No society can be really courteous in which people have to lock everything up for fear of its being stolen, dare not leave a letter on a table for fear of its being 
read, dare not lend a bicycle to a friend for fear that it will not be scrupulously treated, dare not ask another man's advice in a difficulty for fear that he will betray their confidence. People cannot be courteous unless they trust in one another's habitual honesty and kindness.

Within my own lifetime I think there has been a great advance in these matters. Decent people are much less inclined to speak rudely to servants or harshly to children, and it seems to me that they are more ready in the little things of life to avoid thinking needless evil of one another.

I have been too long upon this subject. To sum it up, I believe that the spread of Intellect will be a defence against the dangers of the love of money and the habit of valuing all things by a money standard. That it will diminish "snobbishness" and increase courtesy, and will help us to a better conception of what we call a gentleman : a "Noblesse-Oblige" without the class pride.

Now for the next thing that I expect of you. It is something much more controversial. A friend of mine once asked George Meredith, that profound observer of human life, what he considered the greatest change that had occurred within his lifetime in England. He answered without hesitation, the change in the position of women; and he claimed, very justly, that his own writings had had some influence in the change.

I remember as a boy the discussion that went on about the Married Woman's Property Bill-the second of the two Bills. It will perhaps seem strange to you-I hope it may-that before those Bills were opassed, everything that a married woman possessed, and everything that she earned afterwards, belonged ipso facto to her husband. (The rich of course could elude this by marriage settlements and special contracts.) A drunken husband could practically desert his wife and leave her to work alone for herself and children, and when she was paid her wages he could call at the house and take them. In practice he can often do that still. But at that time, if the woman made any difficulty, the man could simply go to a magistrate and get an order. All that she earned, and all that she could ever earn, belonged by law to her worst enemy. The Acts corrected all that. I do not remember the first Bill, but I heard the second much discussed and furiouisly denounced, especially, I remember, by one particular clergyman. It was laying hands upon the Ark. It was tampering with the sanctity of marriage. It was sowing distrust between husband 
and wife. A woman sometimes suffered through the existing law. True; but if she loved her husband, was it not woman's privilege and pride to suffer for those she loved? If she did not love her husband, she was a bad woman and deserved all she got. Selfsacrifice was a true woman's pride and joy; it should be ours to see that she got plenty of it.

I could give many more reasons if necessary. Now at that time I thought about the whole subject a good deal, and I formed a very clear and decided opinion which $I$ have never seen occasion to alter. It is not the suffrage nor any particular political question that I wish to lay before you now or about which I am forming any special hopes from you. It is the whole question of a better adjustment of the relations between men and women. I feel profoundly that things are not right at present. Neither law nor public opinion has suited itself to the actual movement of the facts. Nay, they never really suited even the old state of facts under which they grew up.

As before, I idealize no class. I admit the existence of more differences between men and women than those of physical strength. I admit that, in certain classes, men generally live by work, and women by inducing men to work for them; that traces of an old condition in which women lived either as slaves or as flourishing parasites, can still be found. But they are only traces. The old condition itself has ceased. Women are working for themselves on every side in hundreds of thousands. They are showing high qualities-no doubt different in some ways from the qualities of a similar set of men, but certainly not in an unqualified sense inferior-in all kinds of work, manual, intellectual and, most of all, practical or administrative. Their advance has been swift and steady; marked by singularly few defeats or failures.

Now I do not insist on any one's approving of this movement. Some thoughtful people think it bad. Study it fairly, and if you think it bad say so. The facts are mostly before our eyes. But I will express my own general opinion-and it has some rather far-reaching consequences-that we must accustom ourselves-and we must begin young - to regard women in all respects and all relations of life as fellow-citizens and not as property. (I hope that the view will be reciprocated.)

Now why 1 look specially to you for guidance and leading on there points is this. In the first place, this new class of intellectual men and women in whom I put my trust will be highly civilized; and it seems to be generally true that every advance in civilisation, 
every step taken further from the realm of greed and brute force, makes more for the freedom of women. In the second place, intellectual people are normally temperate and free from the grosser passions. And this new class will also, I think, be very largely drawn from homes in which a certain Puritan outlook on life, a certain temperance and chastity of thought and conduct, is so habitual as to be almost a second nature. And if we are to think freely and sincerely and without panic on these difficult questions, those qualities more than almost anything else must form our starting point. In the third place, you of all people, in these mixed universities, are actually growing up with women for your comrades and your rivals. It is possible for a certain type of rich young man, who only meets girls in ballrooms, to believe that women have by divine decree no reasoning power. It is not possible for you and me, who see women get prizes in the Logic class. It is possible for a certain type of navvy to say that if his wife beats him-in argument he will knock her down with the poker; such a course is for you and me, if not impossible, at least beset with difficulties. It is from these mixed universities, from the women who work hard and love knowledge, and the men who inevitably become their comrades, that I expect the greatest real advance towards some reasonable solution of the problems that now lie between the two sexes.

Of course I am not advocating any particular measures. That would be beyond my province. I only call your attention to a class of questions which will soon, I think, become pressing, and in which you, if you are true to the spirit of your calling, may give good counsel to the nation. I mean all questions in which the two sexes come into partnership or conflict: marriage, women's work and the payment for it, the feeding, clothing and education of children and the like. Only do not refuse to think. Do not talk about the Ark. If these questions are not settled by reason and fair dealing, they will be settled by force or cunning. Burdens that are not deliberately adjusted always tend to slip on to the weakest shoulders.

I will mention just two or three heads of the problems which I think the next generation will have to face. Consider the position of a young man or woman who, from some sudden impulse, some passion, some weakness, some extreme innocence even, marries a person whose close society becomes hateful or even degrading. Is that unfortunate being to be chained for ever, to be made daily into a worse man or woman, as the result of one 
often most pardonable mistake; is there to be no escape provided by law except through the commission of a crime, or somethi which will entail an extreme of social persecution?

That is the case of a person practically blameless, guilty only of a mistake of judgment in difficult circumstances. But the people whose case is hardest are those who are just not blameless. One who can stand boldly up in complete consciousness of innocence can generally get a hearing. It is the man-or still more the woman-who knows that in part he has dont wrong; who dare not plead his cause because he is ashamed of something or fears some scornful retort, who is exposed under such arrangements as ours to the cruellest penalties. One false step across a prescribed line, and the offender is exposed forthwith to all the pent-up spite and fear and self-righteousness of society. And it would be not so bad if the line in question were drawn in clear and open country. It is drawn in the midst of a forest, in a great half-explored region of human nature, in which the division between right and wrong, between the better and the worse, often seems quite diff rat as you look at it from a distance or from near at hand.

These are nusters for public opinion, not for the law. And no universal rules are applicable. Personally I believe that the surest road to happiness lies through a good deal of self-denial and austerity, even through asceticism. But I would emphatically say to you this : as you love knowledge, be sure in these matters that to some extent you understand before you hate.

Enough of that. Now may I put before you another question, which will come much more closely home to the majority of ourselves. It is clear that in the present state of society the burden and expense of rearing children is so great and, among all but the very poor, is thrown so entirely upon the parents, that practically the whole of the best part of the community, the intellectual middle class, as soon as they marry, must face a prospect of troublesome and sometimes of grinding poverty. That is serious enough in itself. The relief of that burden may be one of the greatest problems for future Chancellors of the Exchequer." But what I want you to consider at the moment is a particular part of the difficulty. In normal circumstances among the professional classes, a quite inordinate share of this burden falls upon the women. In most of the professions they can adopt women are hard driven and

\footnotetext{
- This wa witten bofore the prenent Chancallor had enuounced bi proponels in this direction.
} 
poorly paid. But I am not sure that the wife of a struggling professional man, if she has chítdren, is not worse off than almost any. I have been asked by a lady of my acquaintance to add-I should not dare to say such a thing for myself-that this is one reason why the wives of clever men, when they reach middle age, are so often stupid. They were not stupid to begin with. They meant to share their husband's wider interests. But an anxious and incessant pressure of trivial cares and duties has left them no time to read, no energy to think or use their imagination. There is here a great unconscious oppression, a great wasting of high human life. It is for the coming generation to try and amend it.

And lastly, I cannot leave this great group of questions without touching in three sentences upon the ugliest question of all. No state of affairs is, I will not say satisfactory, but even patiently to be endured by thinking men and women, which has as an integral part of its being-regular, ubiquitous, unceasing, a matter of course in all cities - the fact of prostitution. Do not think that the women affected by that are for the most part specially bad women, or that they take willingly to their trade. Hundreds and thousands of them are driven into it because that way they can live, and in other ways life is too difficult.

It is not our generation nor the next after that that will solve these questions. But they lie before you; and if you do not face them, you thinking men and women of trained intellects, of good lives and governed passions, resolute to understand and to help, I do not know where the people who are suffering can turn for aid. I offer you no panacea of my own. Nothing can be attained by mere severity. Nothing can be attained by hypocrisy. Nothing can be attained by ecclesiasticism. Beyond that I will not go.

The third matter in which I think that the country may look to you and yours for help and good counsel I must touch upon very briefly. It concerns this love of knowledge which must in some degree or other belong to all worthy members of a University. And it concerns politics. We are essentially a political nation; the best informed on politics, the most interested in politics I believe, in the world. Yet it is to me quite amazing how little effort most people make-and how little their rich and highly. staffed newspapers encourage them to make-towards getting accurate and unbiassed information on important questions of public policy. It is the people of course who are to blame, not the newspapers. The newspapers give mainly what the majority of people want. And the majority, except now and again on some 
special question, do not apparently want thorough inquiry or unbiassed statement. They prefer to be guided by party scores, gibes, prejudices or mere accidents-even when they are not actuated by interests which are definitely selfish or corrupt. Think of election placards. One scarcely even expects them to tell the truth. Why? If we really wanted the truth, I can't help thinking we should get it. Our political future will wear a far more hopeful look if ever we can form in the country a really large and strong mass of people who will approach political questions as they would approach a question in science or history, or rather, as a good doctor would approach some question of public health, with the single desire of first finding out the relevant facts, and then acting upon them, of first making out what is best, and then doing it.

I know that this is a good deal to ask. I am first asking my future Intellectuals to look at all public questions solely with a view to the public interest; not to their own or that of their class. Or at least, since that is an ideal which no class in history has ever maintained for long, to try to care most and first for the public interest. Secondly, I am asking them, as far as they can, to free themselves from prejudice. The old radicals of the end of the XVIIIth century used to believe that prejudice was the source of all evil; that, when prejudices were once eradicated, human beings would simply see straight and act straight. I do not quite expect that. But I would venture to ask all intellectual people who find that they have a strong feeling, especially an angry feeling, for which they can give no good reason, always to think carefully before they trust it.

The nearer we approach to this end, the less there will be of that deplorable talk of which we now hear so much, that such-andsuch would of course be the right policy, but the British public would never stand it. The less there would be of the most vulgar and dangerous elements in our new-fangled journalism.

If any class in the country is to make this effort, to rise superior to the cries of interest and passion, to try in all public matters first to find out the truth and then act upon it, I think it should be your class. You start fairly free; you have the training and the ideal; and you are not, like some other classes of the community, the victims of any acute and passion-breeding distress.

There is another region also in which I would ask you to be true to this love of knowledge which is the badge of our profession. You may sometimes find throughout the country, perhaps in Wales, certainly in England and Sootland, most 
abundantly in Ireland, ministers of religion in various sects inclined to denounce the pursuit of higher knowledge because it is unsettling to the students' faith. As to that, I would ask you to face two facts. In the first place, it is not for a moment to be expected, nor yet desired, that a young man's or woman's whole outlook on the world should remain, after three or four years spent in the pursuit and increase of knowledge, exactly the same as it was before. Your new knowledge must add to your understanding. It must make you reject some conceptions that you held before, and form others that you had not thought of. Remember that no true thing can contradict another; fix your minds upon truth and the pursuit of truth, and be faithful to the Love of Knowledge which is the badge of our calling; and you need have no fear that any true thing which you now believe can ever be imperilled by truths that you may learn.

But the Love of Knowledge will take you further than this. In each man or woman who really possesses it, I believe that the Love of Knowledge will act as a purifying and ennobling influence. There is a strange phrase in one of Plato's dialogues about what he calls the "necessities" or "necessary parts" of mathematics. It is in the "Laws," the great work of his old age (pp. 818, 819). He does not mean the necessary minimum of knowledge, without which a man can not do his accounts. "No," says Socrates, " by the necessary part I mean that without which a man cannot become a god upon the earth nor a spirit nor yet a hero, nor able seriously to serve and care for men."

The subject matters little. The important thing is the desire for knowledge. The world is all around and below and above us, the physical world, the mind of man, the records of the unexhausted past. The possible subjects are infinite, and one brain will be fitted for one path of learning, one for another. Learned men may of course become petty and bitter and selfabsorbed, like other people; but it is not those qualities that have made them men of learning. They have mostly been grievous hindrances. The love of knowledge must be a disinterested love; and those who are fortunate enough to possess it, just in proportion to the strength and width of their love, enter into a great kingdom where the strain of disturbing passions grows quiet and even the persecuting whisper of egotism dies at last almost completely away. An inhuman kingdom, some may say; but it is not through love of knowledge that men really become inhuman. It is through much commoner qualities, In the realm of learning we are indeed 
less constantly occupied with other human beings than in most walks of life. Yet we are always conscious of them as comrades and fellow-workers in different parts of the eternal search after truth; we ought always to be conscious of them as fellow-members of the great race in whose tremendous history our lives are but fleeting moments, and to whose needs, each with our several powers or gifts of knowledge, old or new, useful or for the moment valueless, we stand ready to minister.

Gilbert Murray. 